\title{
Gathering of the clans
}

\section{Get in touch with your past.}

\section{Reinaldo José Lopes}

You could see the pavilions for miles around in the bright summer morning. Only a little less conspicuous was the line of people moving slowly towards two signposts. "Got your marker ready? This way, please," said one. "First time? Come and shed your blood," informed the other. And above them, a bigger signpost shouted in fake-Celtic letters: "Welcome to the 5th GATHERING OF THE CLANS! ${ }^{n}$

The enthusiasm was almost palpableor was it the smell of sweat? - except for a tiny segment of the line where a group of friends was arguing. They seemed to be having a hard time convincing one of them that yes, despite the evidence, this was going to be cool.

"Don't be such a baby, Pat. It'll be fun."

"And I still say it's gonna be ludicrous. And I hate needles. Do you really think they'll use a different one for every single person in this crowd?"

"You sound like a sissy. It's just a drop, for goodness sake! You know how efficient those sequencers are nowadays. They read the bases, tell you who was your greatgreat-great-grandpa of a couple of thousand years ago and that's it - you're free to drink mead and get the chicks."

"Yeah, Pat, what's wrong with that? After all, we're just connecting with our past, buddy. Thought you appreciated that."

"Look, I'm as likely to engage in heroworship as anyone. It's the impersonality of it that bothers me. There was certainly a point in us claiming descent from Hengist and Horsa. Those guys at least had a story - they cut Finn and his gang to pieces and conquered Britain. Been there, done that. People can connect with that kind of stuff. But now you're asking me to worship a DNA sequence. No sir - I'd rather go drink mead with old Hengist in Valhalla"

Soon they were right in front of the gates, where a stout fellow in white was grinning at Pat - everyone, of course, had made sure he was the first to get in.

"Alright, mate, what's it gonna be? Mt? Y? Autosomal markers?"

Pat sighed. "Whatever. Surprise me."

Very carefully, his thumb was pierced. Ten seconds later, a robotic voice that seemed to be suffering from a dreadful case of personality emulation (of the irri-

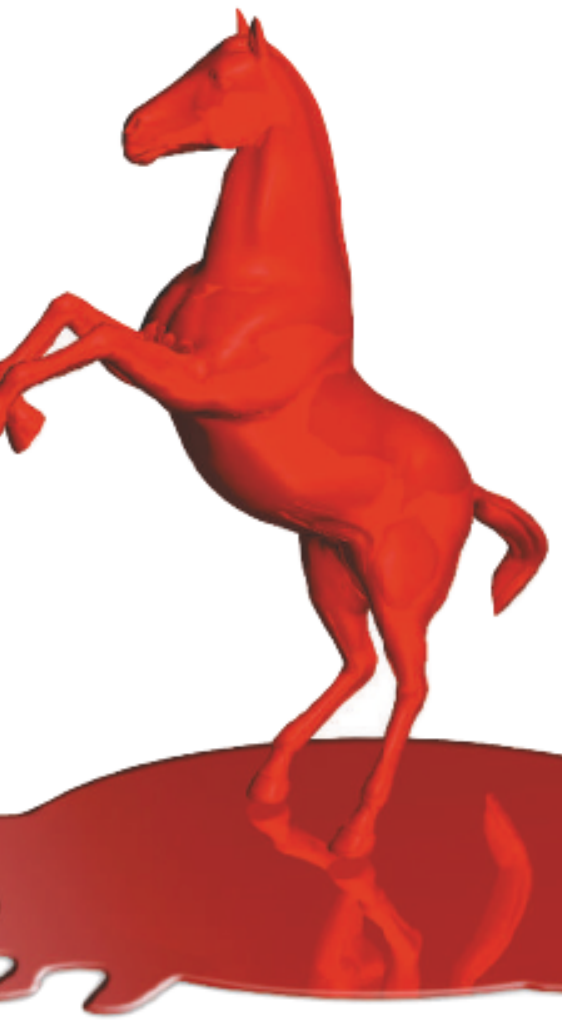

tatingly happy sort) announced: ${ }^{\alpha}$ Congratulations! Your mtDNA has been assigned to the $V$ haplogroup, fairly common in western and northern Europe, where it originated right after the Last Glacial Maximum! Your people were probably among the earliest and greatest artists the human race has known, creating those fine murals of extinct megafauna in Altamira and Lascaux. Way to go! ${ }^{\prime \prime}$

"Thrilling," growled Pat. "Can I go now? ${ }^{n}$

"Hang on a sec," said the gatekeeper, "you need your totem! " He gave Pat a little plastic horse that looked like a poor imitation of the ones from Lascaux. Pat sighed still louder, grabbed the horse and moved on.

"Hey, what's wrong with Marvin there?" asked the gatekeeper.

"Oh, the usual thing. Don't talk to him about life," answered his friends, laughing.

The Gathering seemed to confirm Pat's worst fears. In one corner, somebody dressed as a Mongol warrior was calling "all Star-Cluster kids under ten" to learn how to shoot with a composite bow, just like Grandpa Genghis. A few yards away, some French families were being instructed in the minutiae of cannibalism among the Tupinambá tribes of Brazil it turned out a young chief from that nation had married the daughter of a
Norman trader in the sixteenth century. Elsewhere, a rabbi was always ready in case you found out your chromosomes were Jewish and wanted an impromptu bar mitzvah.

Pat wandered miserably until he spotted a girl with long black hair who also seemed to be walking alone. Predictably, he was happy to inflict on her (Vera was the name, and she was from the Basque Country in Spain) all the talk about how ridiculous the whole Gathering concept was. Vera seemed to dig his grumpy-oldman charm, but didn't quite agree.

"I think everyone is aware of that stuff," she said "But think of it for a second. Isn't it wonderful that all these different people are learning about a past that seems plain legend but is written in our blood? Besides, look at the scale of it. We
used to think in terms of two or three generations at most. Now you can look back thousands of years and still recognize yourself."

Pat was still unconvinced. "I see what you mean. But I don't know quite how to feel about it. You see, I. .. Whoa!"

They had wandered to the very heart of the Gathering and were right in front of an awesome panel. Picture the largest family tree you have ever seen, hundreds of feet across. There was a huge 'YOU ARE HERE' on the right side, and all the lineages of men (well, of women, actually, because it was an mtDNA family tree) ramified from 'EVE' on the left, crowned with their achievements, from the Internet to, yes, the horses of Lascaux.

"Well, I don't think you can argue with that," muttered Pat.

"I guess you can't," smiled Vera.

"You didn't tell me what your dan was," he asked.

"Oh," said Vera, "here it is." She showed him a plastic horse.

It was only his imagination, but he could almost see Vera in a different guise altogether. She was clad warmly in fur, and in ochre the most fantastic designs graced her white skin. She raised a torch and, for a split second, all the beasts of the Ice Age danced in the rock roof. There was only one thing to do: he kissed the apparition.

"You don't think that counts as incest, do you?" joked Pat. She laughed.

Reinaldo José Lopes is a science writer at Folha deS. Paubo, Brazil's leading daily newspaper. Hecanbe reached at rlopes@folhasp.com.br. 